\title{
THE RACE TO THE BOTTOM: Incentives for New Investment?
}

\author{
Bruno Gurtner, Chair of the Global Board \\ John Christensen, Director of the International Secretariat \\ tax justice network
}

\begin{abstract}
Tax competition is one of the strongest credo of orthodox economic policy. However, empirical evidence suggests that tax incentives are not effective as tools for attracting foreign direct investment, but instead promote a race to the bottom in taxation of corporate profits, whilst also harming democratic forms of government and the ability of states to provide public services to their citizens. Tax competition is accompanied by a fierce regulatory competition leading to a race to the bottom on international financial regulation. The latter has facilitated the establishment of a huge shadow banking system which lies at the root of the present international financial crisis.
\end{abstract}

A pro-poor development consensus needs a new tax agenda. The Follow-up International Conference on Financing for Development in Doha (End of November /early December 2008) offers an opportunity to bring taxation to the heart of the development discourse. The Tax Justice Network has taken a lead role in promoting this dialogue. 


\section{Introduction}

Tax competition has been one of the strongest of the credos of orthodox economic policies: Nobel prize winning economist Milton Friedman from the University of Chicago has promoted tax competition, saying:

"Competition among national governments in the public services they provide and in the taxes they impose, is every bit as productive as competition among individuals or enterprises in the goods and services they offer for sale and the prices they offer. ${ }^{1 "}$

Others have written "Tax Competition is good. It restrains the appetite for higher taxes, it prevents tax cartels, it promotes investment and economic growth. It spurs productivity and innovation. Tax competition creates pressure on states to become more efficient in how they raise and spend taxes. It gives investors the choice between different locations according to the tax levels compared to the benefits provided"2.

The Economist magazine has also supported the argument that tax competition can spur public sector productivity, but has not published empirical evidence to back this proposition, instead relying on the statement of a Swiss banker that "Tax competition in the only agent of productivity for governments - it is the only competition they have." (The Economist, 2007). The highly political nature of this statement has been criticized by commentators, not least since it ignores the role of electors in choosing between governments offering high-tax/highspend and low-tax/low-spend alternatives. ${ }^{3}$ This propensity to over-ride the disciplinary force of democratic choices is common to the analysis of all the proponents of tax competition.

Tax competition is strongly championed by the US-based Heritage Foundation through its associated lobby, the Center for Freedom and Prosperity (CFP). The CFP is a vociferous supporter of tax havens (though they prefer the term low-tax regimes, which is misleading) arguing that "low-tax regimes must aggressively defend tax competition as a liberalising force in the global economy. They should argue that tax competition has helped lower tax rates and reduce discriminatory taxes on income that is saved and invested." (CFP, 2003). The CFP has also taking a leading role in condemning attempts to strengthen international cooperation on tax matters, for example through the implementation of the European Union Savings Tax Directive (designed to create a framework for automatic exchange of tax information between national authorities of EU Member States) arguing that this effort at international cooperation - intended to protect the national sovereignty of European tax regimes from offshore tax evasion - is a step towards tax harmonisation.

Opponents of tax competition, however, are concerned that the aggressive practices of tax havens (and the financial and legal specialists who operate from such places) demonstrate the emergence of a beggar-thy-neighbour culture in international relations. Left unchecked

\footnotetext{
http://www.freedomandprosperity.org/ accessed 17 March 2007

${ }^{2}$ Federal Department of Finance Switzerland, Steuerwettbewerb (Tax Competition) In German only, www.efd.admin.ch .

3 See, for example, http://taxjustice.blogspot.com/2007/03/economist-goes-offshore.html
} 
this tendency towards economic aggression will stimulate a race to the bottom affecting both tax and regulation. Reuven Avi-Yonah, for example, argues that for states to be able to meet their commitments to welfare provision and development programmes in the face of the fiscal pressures of globalisation, governments will need to cooperate in order to limit the scope for tax competition, whilst at the same time retaining their ability to determine the size and nature of their state sector through the normal democratic processes (Avi-Yonah, 2003).

Noting the highly politicised nature of tax competition Richard Murphy, Senior Adviser of the Tax Justice Network, has commented that "...tax competition lies at the heart of the neoconservative agenda". Tax competition is "designed and promoted by political and commercial interests acting on behalf of a tiny minority in society". Murphy rejects the ideological justification of the neo-conservative promotion of the tax competition and finds no empirical evidence to support their view that tax competition acts as a helpful agent in disciplining high tax - high spend governments into greater expenditure efficiency. He considers tax competition as harmful (Tax Justice Focus, Volume 3, Fourth Quarter 2006). Looking at the context of tax competition within the enlarged European Union, Drezet notes that the use of tax competition by recent accession member states on the eastern EU periphery has "degraded public goods and services and transferred the tax charge (through indirect taxes) onto the less mobile, most notably working people, the unemployed, pensioners . . "(Drezet, 2005)

Tax competition occurs when governments are encouraged to lower fiscal burdens to either attract an inflow of productive resources or discourage the exodus of those resources. Often, this involves a governmental strategy of attracting foreign direct investment, foreign indirect investment (financial investment), and high skilled human resources by minimizing the overall taxation level and/or special tax preferences. Tax regimes in many countries, and in different states within federated states like India or the United States, have been shaped as tools for industrial aid policy, in many cases involving exemptions or incentives that are specifically targeted at subsidising relocation of investment that might otherwise be more profitably located elsewhere. Concerns about how the connection between tax policy and state aid policy might distort investment were central to the European Union's code of conduct on business taxation initiated by the European Council in December 1997. The code of conduct defines harmful tax competition - see box 1 below - and extends to all EU member states plus their dependent territories. The implementation of the code of conduct involved the European Commission, working through a Council Group (the Primarolo Group, named after its chair, Dawn Primarolo MP, Paymaster General to the UK Treasury) to undertake a peer review process of the tax regimes of all member states to identify and remove potentially harmful tax measures. To date the Group has struggled to arrive at agreement across all Member States on which measures are deemed harmful, and its process has been criticised by both the business communities and NGOs for lacking transparency and legitimacy (Radaelli, 2003) 


\section{Box 1: How the EU code of conduct on business taxation defines harmful tax competition}

A. Without prejudice to the respective spheres of competence of Member States and the Community, this code of conduct, which covers business taxation, concerns those measures which affect, or may affect, in a significant way the location of business activities in the Community. Business activity in this respect also includes all activities carried out within a group of companies. The tax measures covered by the code include both laws or regulations and administrative practices.

B. Within the scope specified in Paragraph A, tax measures which provide for a significantly lower effective level of taxation, including zero taxation, than those levels which generally apply in the Member States in question are to be regarded as potentially harmful and therefore covered by this code. Such a level of taxation may operate by virtue of the nominal tax rate, the tax base or any other relevant factor.

Source: Official Journal C2, 6.1.1998

Tax competition pressures have largely arisen from the processes of trade and capital market liberalisation. In the absence of capital controls, and under pressure to remove trade tariffs and taxes, sovereign states have been pressured into lowering their corporate tax rates and using other tax incentives, especially tax holidays, in order to attract foreign direct investment. Tax incentives can be defined as a fiscal stimulus provided to specific investors or categories of investors as an inducement to act in accordance with the development strategy and investment goals of the government offering the incentive. Incentives come in a variety of forms, with UNCTAD identifying eight broad categories classified on the basis of their targeted income (table 1):

Table 1: Main categories of tax incentives

\begin{tabular}{|l|l|}
\hline Category & Specifications \\
\hline $\begin{array}{l}\text { Profits / income } \\
\text { based }\end{array}$ & $\begin{array}{l}\text { Reduction of the standard corporate income tax rate; tax holidays; } \\
\text { loss carry forward or carry back to be written off against later (or } \\
\text { earlier) profits }\end{array}$ \\
\hline $\begin{array}{l}\text { Capital investment } \\
\text { based }\end{array}$ & $\begin{array}{l}\text { Accelerated depreciation; investment and re-investment allowance; } \\
\text { tax free interest payments; R\&D credits }\end{array}$ \\
\hline Labour based & $\begin{array}{l}\text { Reductions in social security contributions; deductions from taxable } \\
\text { earnings based on employee numbers or other labour related } \\
\text { expenditure }\end{array}$ \\
\hline Sales based & Income tax reductions based on total sales \\
\hline Value added based & $\begin{array}{l}\text { Income tax reductions or credits based on the net local content of } \\
\text { outputs; income tax credits based on net value earned }\end{array}$ \\
\hline
\end{tabular}




\begin{tabular}{|l|l|}
\hline $\begin{array}{l}\text { Based on other } \\
\text { expenses }\end{array}$ & $\begin{array}{l}\text { Income tax deduction based on e.g. expenditures relating to } \\
\text { marketing and promotional activities }\end{array}$ \\
\hline Import based & $\begin{array}{l}\text { Exemption from import duties on capital goods, equipment or raw } \\
\text { materials, parts and other production related inputs }\end{array}$ \\
\hline Export based & $\begin{array}{l}\text { Output related: exemptions from export duties; preferential treatment } \\
\text { for income from exports; tax credits on domestic sales in return for } \\
\text { export performance, etc }\end{array}$ \\
$\begin{array}{l}\text { Input related: duty drawbacks; capital allowances for export industries; } \\
\text { tax credits for duties paid on imported materials or supplies; income } \\
\text { tax credits on net local content of exports }\end{array}$ \\
\hline
\end{tabular}

\section{Source: UNCTAD, 2000}

The notion of the "race to the bottom" suggests that tax competition (and the related issue of regulatory competition) will catalyse a downwards spiral of tax cuts and other incentives as a result of the intense rivalry between countries to attract investments and location of enterprises and rich individuals. The advantage gained by one country from lowering its taxes is often short term because it is quickly offset by similar moves in neighbouring countries. This beggar-thy-neighbour process of undercutting has been observed in a number of regions, with some tax havens in the European region, e.g. the islands of Guernsey, Jersey and the Isle of Man, leading the way by offering zero tax rates to both resident and nonresident companies.

Despite numerous studies the economic debate over the impact of tax competition remains controversial. It is notable that empirical studies have not supported the notion that tax incentives play a significant part in attracting foreign direct investment or retaining domestic resources for local investment. Two major studies, one focusing on developing countries and the second on developed countries, have concluded that tax incentives serve little purpose and may even be counter-productive. The consulting business McKinsey \& Co published a study of fiscal inducements in China, Brazil, Mexico and India, and concluded that these inducements might have had negative and unintended consequences:

"Without materially affecting the volume of investment in most cases, popular incentives such as tax holidays, subsidized financing or free land, serve only to detract value from those investments that would likely be made in any case." (McKinsey, 2004)

An unrelated study of tax incentives in the United States concluded that there are:

"little grounds to support tax cuts and incentives - especially when they occur at the expense of public investment - as the best means to expand employment and spur growth. Tax increases used to enhance public services can be the best way to spur the economy. By stimulating growth, generating jobs, and providing direct benefits to 
residents, improvements in state and local public services can be one of the most effective strategies to advance the quality of life of citizens." (Lynch, 2004)

Which begs the question, why do governments persist with offering fiscal inducements when the evidence suggests that good social and physical infrastructure, an educated workforce, and stable social and economic conditions are a more important pre-requisite for investors? The answer lies with the fact that governments are under immense lobbying pressure, particularly from business consulting firms, to offer tax incentives in order to attract inwards investment (Christensen and Kapoor, 2004). In general it can be assumed that governments would prefer to refrain from offering tax incentives if there was agreement to avoid this process of undercutting one another by granting such incentives (Avi-Yonah, 2000).

In addition, intense competition between developing countries (the majority of which have under-resourced tax departments) enables TNCs to exert their considerable political influence to secure preferential tax treatment. This also opens up space for corrupt practices, as is alleged to have happened in Nigeria, where multinational oil services giant Halliburton stands accused of bribing tax officials.

\section{Harmful effects of the tax competition}

For the Tax Justice Network (TJN) the harmful effects of this tax competition heavily outweigh any possible benefits (TJ Briefing: Tax Competition; Tax Justice Focus 2006, Vol. 2, Number 4; International Tax Co-operation and Competition, Resource Paper).

Firstly, tax competition undermines democracy. This kind of "competition" between countries generates external pressures that undermine the right of electorates to decide whether they want to live in a high-tax or low-tax economy, or how to organize the relative weights of different forms of taxation within the economy. It inhibits government from providing the tax systems their electorates vote for, and even threatens the viability of tax regimes and nation states:

"Competition theory belongs to the world of microeconomic theory in which consumers make informed choices between suppliers of goods and services, and companies that fail to adapt go bankrupt and are replaced by more efficient ones. Proponents of tax competition casually assert that market competition is like tax competition, but this is false. In liberal democracies, it is electors - not consumers who control choices between one government and another. A failed company is one thing. A failed state is another thing entirely." (Christensen, 2008)

This view of the political nature of tax competition is shared by Martin Wolf of the Financial Times, who has commented that "the notion of the competitiveness of countries, on the model of the competitiveness of companies, is nonsense." In subsequent discussion on the Financial Times' Economists Forum, Martin Wolf stated that: "I would focus on two objectives. Full information sharing across the globe; and development of a common base for 
corporation tax that prevents companies shifting income into offshore tax havens. Both seem to me legitimate efforts." ${ }^{4}$

Second, tax incentives distort markets. These investment incentives are discriminatory in so far as they provide a significant financial advantage to external investors and put local businesses at a disadvantage. This unequal treatment is compounded by the ability of transnational companies to make extensive use of offshore tax vehicles for profits shifting purposes, thereby undermining the integrity and equity of tax structures and creating a freerider economy

Third, tax competition results in the tax charge being shifted from capital (a highly mobile factor of production) towards less mobile factors such as labour, and onto consumers. The relative tax burden on corporations has fallen, while the tax burden on labour and spending has risen. This shift in relative costs leads to a reduction in demand for labour, hampering job creation, whilst also increasing post-tax earnings to capital. Income inequality - one of the great economic challenges of our age - has increased sharply as a consequence (Diesch, 2007). Domestic wealth and income inequality has increased in the majority of developed countries and to an even greater extent in developing countries.

In general weaker states are less able to cope with the external pressures of tax competition, resulting in a lower revenue base. In their 2006 paper on capital mobility and corporate tax rates, Dutch researchers Garretsen and Peeters investigate how competitive pressures differ from country to country according to the extent of agglomeration of industrial activity. Based on empirical studies they conclude firstly that international capital mobility has exerted downwards pressure on the corporate tax rate: secondly, and importantly, they also conclude that agglomeration is an important determining factor: their evidence supports the hypothesis that more centrally located and agglomerated countries are able to sustain higher corporate tax rates that less centralised and agglomerated countries. This suggests that peripheral states, which includes the majority of developing countries, are more vulnerable to pressures from multinational companies to provide tax incentives (Garretsen and Peeters, 2006)

Declining tax revenue forces governments in developing countries to substitute other taxes, typically indirect taxes with a consequent regressive impact on wealth and income distribution. Falling tax revenues undermine the states' ability to provide services for their citizens. They force cutbacks in public investment in education, health, transport and other infrastructure, reducing investment and slowing growth. Greater dependence of foreign aid and a weaker accountability of government are the result.

Despite these harmful effects countries continue to offer a wide range of tax incentives and advantages to attract mobile capital to locate in their countries, and those countries that do not offer incentives are likely to come under heavy political pressure from transnational companies to do so. This is especially the case with mineral exporting economies. So governments are lowering their corporate tax rates, offering property tax abatements, accelerated depreciation rates, corporate income tax credits, subsidised infrastructure and

${ }^{4}$ http://taxjustice.blogspot.com/2008/06/martin-wolf-on-tax-competition.html 
energy, sales tax exemptions. They are partitioning off parts of their territories into special commercial regions in which the burdens of taxation, as well as other regulatory requirements, are less than they are in the rest of the country (Export production zones, free trade zones). They are offering low or zero tax rates for specific types of business, usually limited to those owned by non-residents, such as financial services and holding companies (Offshore Financial Centres). In that sense tax competition typically involves special schemes and narrow incentives which are discretionary, selective and secret, resulting in distorted markets and more opportunities for corruption.

Tax holidays are amongst the most frequently used forms of tax incentive, and they are especially popular amongst governments of developing countries. Tax holidays provide qualifying companies with an exemption from paying tax on corporate profits or other tax liabilities for a fixed period, generally between five to ten years, but occasionally for longer periods. The attraction of tax holidays to governments lies with their simplicity - they require no monitoring and do not involve budgetary commitment, though there is clearly a loss of revenue income. The disadvantage of tax holidays lies with the fact that companies that make profits in the early years of operation are frequently mobile and can simply relocate to a different country at the expiry of the fixed period. There are numerous examples of this happening in practice in both developed and developing countries (UNCTAD, 2000).

The employment of tax incentives tends to vary according to the developmental goals of different countries. Countries aiming to promote an export led development strategy are likely to provide export processing zones as a means of obtaining foreign exchange and developing a local skills base. Some countries use research and development tax credits and tax-exempt technology development funds as a means of achieving technology transfer and building comparative advantage in specific technology sectors. Conceptually, if the long term gains from these incentives, in the form of job creation, local procurement and tax revenues, exceeds the short term costs, and if the tax incentives played a decisive role in attracting the investment in the first place, there is a case for providing incentives. In practice, however, investment decisions are most likely to be based upon key economic criteria, including macroeconomic stability, availability of production inputs, labour productivity, strength of domestic markets, and the absence of institutional barriers to investment. McKinsey concluded that tax incentives are seldom required and can distort investment decisions to the detriment of production efficiency (McKinsey, 2003). This conclusion is supported by studies of investment behaviour which show, unsurprisingly, that at the level of the firm tax incentives are less relevant in sectors in which countries already enjoy a comparative advantage (Qiu, 2003) and that tax incentives rank low on the firm's investment priority list. This conclusion does not, however, hold good for investments directed as export oriented production (e.g. electronics assembly and similar "screwdriver" activity) which is frequently not location-specific and therefore more likely to generate competition between countries.

Behind the promotion of tax competition there are other reasons and goals. International companies and mobile rich individuals are misusing instruments of tax competition for crossborder abusive tax evasion and tax avoidance. Tax incentives serve only to detract value 
from investments that would likely be made in any case (McKinsey, 2003; Cobham, in Tax Justice Focus 2006, Vol 2, No. 4).

\section{Regulatory competition}

Worse still, not only is tax competition undermining government revenues and offering possibilities for tax evasion, but it is also accompanied by regulatory competition. Secrecy jurisdictions provide 'light-touch' regulation, which, it is argued, encourages risk-taking. But the current banking crisis reveals how secrecy has allowed risk to be disguised within highrisk instruments - particularly collateralised debt obligations - that have been sold throughout the world with little or no knowledge of inherent risk. This is a lethal combination: when markets are booming there is no pressure on regulatory authorities to correct asymmetric information between sellers and buyers. The nature and scale of risks only materialise when the downturn comes.

Secrecy jurisdictions, with the light-touch regulatory practices, have catalysed the emergence of a huge shadow banking system. Structured Investment Vehicles (SIVs) have been created by banks as artificial structures off the banks balance sheets, frequently for the purposes of raising capital offshore through an apparently separate entity that enjoys a higher credit rating than its parent company and can therefore borrow on the wholesale financial markets at preferable terms. Competition between tax havens is fierce, and their regulators have tended to be particularly lax in regulating shadow banks and hedge funds. Recently European jurisdictions, notably the Channel Islands, Ireland and Luxembourg have been "streamlining" regulation, to attract funds (Stewart, in Tax Justice Focus September 2008). In 2008, Jersey authorised the launch of entirely unregulated hedge funds.

At the end this regulatory competition between secrecy jurisdiction leads to a disastrous race to the bottom. Worse still, financial activities and structures may be split across a multiplicity of jurisdiction none of which have responsibility for regulatory oversight of the entire structure.

\section{Tackling harmful tax competition}

The threat of abusive tax avoidance and the beggar-thy-neighbour strategies of tax havens has led in recent years to attempts to establish a framework of rules to protect national tax regimes from aggressive tax planning and to improve international cooperation in tax matters. A principal actor has been the OECD with its concept of 'harmful tax competition initiative', first launched in 1998 at the request of G-7. The goals of this initiative included a radical transform of secrecy jurisdictions through increased transparency and improved information exchange between national authorities (OECD, 1998). This initiative has been weakened by refusals to cooperate on the part of Switzerland and Luxembourg, both important financial centres.. Other players, including a small island lobby organised under the banner of the International Trade and Investment Organisation (ITIO) strongly supported by the British Commonwealth Secretariat and the Society of Trust and Estate Practitioners, also placed barriers in the way of the OECD process by making cooperation conditional on the adoption 
of a "level playing field" in the treatment of OECD secrecy jurisdictions (e.g. Austria, Luxembourg, Switzerland, United Kingdom) and non-OECD secrecy jurisdictions. The coup de grace for the OECD initiative was delivered by the Bush administration in 2001, when it withdrew its support. Progress on improving information exchange has been modest (David Spencer, International Taxation 2006). The reasons for this limited effect of counter-action against harmful tax competition may be due to the fact that politically powerful capital exporting countries are not affected in the same way and to the same extent as the mediumand low-income capital importing countries.

Despite the formidable resistance to the OECD initiative, pressure for change is building up in both developed and developing countries. Some regional initiatives have been started to counter the pernicious effects of tax competition. The European Union has initiated efforts to co-ordinate tax policies. And the OECD has launched a dialogue with the secrecy jurisdictions. A new IMF Working Paper on Corporate Income Tax in Moldovia concludes that tax competition has led to a decline in tax revenues and greater income inequality. Tax coordination, whilst politically problematic, could help stem further decline in yields from corporate taxation. Without tax coordination, the paper concludes, it would be unclear what exactly could stop corporate tax rates from falling further. The paper also concludes that corporate taxes have only a minor impact on FDI compared with quality of governance, business climate, the quality of the infrastructure, the size of the domestic market, the distance to main markets in Western Europe, labour costs (Piatkowski and Jarmuzek, IMF 2008).

\section{Taxation at the centre of the development discourse}

But the most promising sign of changing times is the fact that taxation has now been firmly established - in a rather remarkable way - at the heart of the development agenda and discourse. The IMF provides a useful pointer to highlight this shift of focus. In a recent IMF quarterly Finance and Development Magazine, Sanjeev Gupta and Shamsuddin Tareq propose that expanded tax bases are excellent way of mobilising domestic resources for development, and acknowledge the need to rationalise tax incentives. "Such incentives not only shrink the tax base but also complicate tax administration and are a major source of revenue loss and leakage from the taxed economy" (Gupta and Tareq, 2008)

Tax reform will become in the long run a major instrument of development financing. It is increasingly recognised that steps to assist poorer countries to move beyond aid and debt dependence will require measures to strengthen the internal tax systems in the developing countries as well effective ways to tackle illicit capital flows and capital flight, tax evasion, unnecessary tax exemptions and the activities of secrecy jurisdiction. These issues will feature prominently on the agenda of the forthcoming UN Follow-up Conference to review the implementation of the Monterrey Consensus (Financing for Development) in Doha starting on 29 November and ending on 2 December.

The Monterrey Consensus, agreed in 2002 at the International Conference on Financing for Development, only postulated modestly "effective, efficient, transparent and accountable 
system for mobilizing public resources" and an "equitable and efficient tax system and administration" (Paragraph 15, Monterrey Consensus on Financing for Development, UN 2002). Importantly, however, the Consensus added in Paragraph 64: "Strengthen international tax cooperation, through enhanced dialogue among national tax authorities and greater coordination of the work of the concerned multilateral bodies and relevant regional organizations, giving special attention to the needs of developing countries and countries with economies in transition". But there was no concrete action plan to bring these ideas into real policy measures.

This was a rather weak and disappointing outcome. Some preparatory documents of the 2002 Conference on Financing for Development had highlighted in a much stronger way the problems of capital flight, tax evasion and the harmful role of secrecy jurisdiction (Zedillo, 2001). But the proposals to tackle these barriers to sustainable development met strong opposition from the rich countries and their satellite offshore financial centres and were eventually excluded from the conference outcome document.

But fundamental changes have happened since the 2002 conference in Monterrey. Firstly, in the international economic context, cross border financial flows and investment have increased due to further deregulation of exchange restrictions and capital controls. Volumes of cross-border trade in goods and services have continued to increase. The structure of transnational companies and of international production networks has become more complex.

Secondly, the growth of trade and investment has been accompanied by a significant growth in the use of offshore financial structures and secrecy jurisdictions. Bank secrecy, shell companies, trusts and anonymous foundations provide international players with the possibility to establish complex products and vehicles to avoid tax obligations. The use of such structures has mushroomed, but this fact has by and large not been recognised by the Bretton Woods institutions and other international organisations.

Secrecy jurisdictions might appear as small and relatively insignificant places. They seldom featured in the past in mainstream academic texts and most analysts and journalists have either ignored them or treated them as externalities beyond the political economic mainstream. This lack of attention is all the more surprising when you recognise that major financial centres like the City of London, Luxembourg and Zurich are all based in secrecy jurisdictions, and many of the 'islands in the sun' such as the Bahamas, the Cayman Islands, the British Virgin Islands, the Channel Islands, Bermuda, Gibraltar and others, act as satellites to these major financial centres.

\section{The opaque offshore world}

Some figures about this offshore world: Over half of all international bank lending and approximately one-third of foreign direct investment is routed via secrecy jurisdictions. 50 percent of global trade is routed on paper via such jurisdictions even though they only account for some 3 percent of world GDP. Over two million international business corporations and hundreds of thousands, possibly millions, of secretive trusts and 
foundations have been created in secrecy jurisdictions. Personal wealth totalling US $\$ 11.5$ trillion has been shifted offshore by the super-rich (known in banking circles as High-Net Worth Individuals), evading taxes of over US $\$ 250$ billion annually (Tax Justice Network, The Price of Offshore, 2006). Secrecy jurisdictions have also played a major role in the sub-prime banking crisis that emerged in 2007, providing an environment of lax regulation which, combined with the opacity and complexity of structured investment vehicles and collateralised debt obligations, has undermined the efficiency of the capital markets

This banana industry case, published in the Guardian newspaper on November 6, 2007, illustrates the point ${ }^{5}$. The value of international trade in bananas exceeds US $\$ 50$ billion a year. The three companies that dominate this trade use secrecy jurisdictions to shift profits by means of packaged intellectual property rights, thus minimising tax payments and maximising profits. Almost half of the final retail price of a banana produced in Latin America and purchased in Europe is accounted for by 'costs' inserted into the value chain by subsidiaries in secrecy jurisdictions. For every 100 pence worth of bananas sold to UK consumers, 8 pence goes to a Cayman company for use of the purchasing network, 8 to Luxembourg for use of financial services, 4 to Ireland for the use of the brand, 4 to the Isle of Man for insurance, 17 to Bermuda for use of the distribution network. Only 13 pence remains in the producing country, of which a mere 1.5 pence is paid for labour costs.

There is no economic substance to any of the activities booked in these tax havens, but the outcome of these complex and secretive structures is that tax payments at both ends are minimised to less than one per cent of the entire value chain, despite these companies' super-high profits. Offshore secrecy provides a high degree of immunity from investigation and prosecution, creating an enabling environment within which a wide range of corrupt practices can be transacted with relative impunity.

Christian Aid has calculated that just two forms of tax evasion, transfer mispricing within multinational corporations and falsified invoicing between apparently unrelated companies, cost the developing world US $\$ 160$ billion a year in lost revenue (Christian Aid, 2008). That figure alone represents more than 150 per cent of the combined aid budgets of all donor countries.

Africa, with its large natural resource base, is highly vulnerable to capital flight and tax evasion: the Democratic Republic of Congo (DRC), for example, lost an estimated US\$15.5 billion due to capital flight between 1980 to 2006 (GFI, 2008). DRC also provides a case study of how MNCs have created opaque and complex offshore structures to evade taxes in the resource extraction industries. Greenpeace International, working with the Tax Justice Network, has uncovered how Switzerland-based logging company, the Danzer Group has been exporting timber products at below world market price to shift profits out of the Congo to its offshore subsidiary, Interholco (Greenpeace, 2008)

The OECD guidelines to control transfer pricing within MNCs - using the 'arms-length' pricing technique - have had little impact in terms of reducing transfer mis-pricing. The guidelines,

\footnotetext{
${ }^{5}$ http://www.guardian.co.uk/business/2007/nov/06/12
} 
which assume a world market price for highly specialised products, services and intellectual property rights, have introduced complexity but provide little guidance on how to price goods traded solely between subsidiaries of a multinational company, and on how to price intellectual property rights (brands, logos, management systems, etc.) the ownership of which is increasingly located in special purpose vehicles registered in tax havens for tax avoidance purposes. Other attempts to tackle illicit financial flows have been timid and unproductive, largely because the international organisations charged with tackling illicit financial flows have taken too narrow a definition of what constitutes money-laundering (Christensen and Spencer, Financial Times, 2008).

Developing countries are particularly vulnerable to illicit financial flows. In many cases, their reliance on the extractive industries and natural resources, exposes them to a higher risk of falsified invoicing and transfer mispricing. This vulnerability is intensified by the fact that their national administrations frequently lack the resources to engage in lengthy investigations into aggressive tax avoidance structures. This administrative constraint is illustrated by the fact that, according to one tax expert, to date not a single African country has managed to successfully conclude an investigation into transfer mispricing (Murphy, Christensen and Kapoor, 2007).

Another major form of capital flight is the transfer of the assets and income of high net worth individuals (HNWIs). There are many and varying reasons why wealthy people might want to shift their capital out of their countries, but in almost all cases tax evasion plays a major role. The possibilities that tax havens offer for tax evasion create powerful incentives for wealthy domestic asset holders in developing countries to retain their assets offshore. So tax evasion and flight of capital are intricately linked. Doing this on an anonymous basis through secrecy jurisdiction enables them to protect their wealth from potential currency devaluation and from taxes, including inheritance taxes.

Even the more sophisticated African countries are severely impacted by tax evasion. The South African Revenue Service, for example, has published estimates of the tax gap in that country ranging up to $\mathrm{R} 30$ billion (45\% of government revenue), largely due to evasion by rich individuals and avoidance by companies. In 2005, the Kenyan Revenue Authority revealed that it was owed a staggering US $\$ 1.32$ billion in unpaid taxes, much of which, according to KRA Commissioner-General Michael Waweru, was probably unrecoverable. This sum represented approximately one half of the total government revenues for Kenya, which at that time had external debts amounting to US\$6 billion (Guindja and Christensen, 2005).

The World Bank's Stolen Asset Recovery initiative reports that the cross-border flow of proceeds from criminal activities, corruption and tax evasion amount to between US $\$ 1$ trillion and US $\$ 1.6$ trillion a year: approximately half of this flow originates from developing and transitional economies.

But not all the capital that flees developing countries stays out: some returns disguised as foreign direct investment. This is the consequence of the flight money being re-cast once it has been shifted offshore, typically by being transferred to the ownership of a special purpose vehicle set up on behalf of the true beneficial owner. This is a process known as 'round tripping', which enables residents of a country to disguise their ownership of capital in order to 
take advantage of the tax incentives offered to foreign investors. Round tripping also occurs when investors see opportunities to buy domestic assets at bargain basement prices, for example during privatisation programmes and after currency devaluation. Round tripped capital is also involved in illicit funding of political parties, bribery of public officials, market rigging, insider dealing, and other corrupt and illegal activities. The fact that ultimate ownership of the capital is disguised through offshore secrecy arrangements provides a very high level of immunity from investigation by revenue and law enforcement agencies, and in most cases even the major international commercial investigation agencies find it difficult if not impossible to penetrate the multi-jurisdictional structures created to perpetrate such crimes.

\section{Capital flight and finance for development}

Since the 2002 International Conference on Financing for Development in Monterrey it has become clear that the scale of tax evasion and capital flight far outweighs aid flows and debt relief programmes. Common sense dictates that capital flight impacts negatively on capital scarce economies. The loss of domestic savings leads to lower levels of internally funded investment. The loss of tax revenues flowing from those savings leads to lower revenues available for public expenditure on health, education and public infrastructure. Using external borrowings to finance government deficits imposes a debt servicing burden which impacts heavily on economic growth and social stability. More aid results in higher dependency and imposition of external determined conditions, which undermines the crucial accountability relationship between citizen and state that tax brings to the democratic processes.

It is clear: capital flight and tax evasion represent significant barriers to the process of enabling developing countries to finance their development from domestic resources. The 2002 Monterrey Consensus highlighted domestic resource mobilisation in both public and private spheres as essential to sustaining productive investment and increasing human capacities. But domestic resource mobilisation cannot succeed without major fiscal reform at national level to tackle endemic tax evasion and remove the high existing level of unnecessary exemptions. National reforms need to be accompanied by complementary measures at international level to strengthen cooperation in tackling abusive transfer pricing, harmful tax competition, and other practices that undermine the fiscal autonomy of sovereign states.

These are ideas and proposals brought into the preparatory process of the coming Monterrey Consensus review conference by numerous developing countries, progressive industrialized countries, academics and civil society organisations from the North and the South, including the Tax Justice Network which since 2006 has been promoting a range of regional and global measures to improve financial market transparency and strengthen international frameworks for cooperation - see Appendix 1.

\section{The opportunity of Doha}

The result of all these written inputs, statements at consultative meetings, seminars and workshops are highlighted in the U.N. Secretary-General's report to the General Assembly in 
the run-up to the Monterrey Consensus review conference in Doha (UNO, Report 2008) and is reflected in the Draft Outcome Document of the Doha Conference (UNO, DOD, 2008) ${ }^{6}$.

Among others we can cite the following references to tax, capital flight and illicit financial flows:

- Fiscal reform is key to enhancing macroeconomic policies and mobilizing domestic resources (DOD Para 8);

- Increase tax revenues through more effective tax collection and modernization of tax legislation, including through simplification of the tax system, broadening of the tax base and strongly combating tax evasion (DOD Para 10);

- Enhance international cooperation in tax matters, and broaden participation in the development of international tax norms and rules. Strengthening the Committee of Experts on International Cooperation in Tax Matters (DOD Para 10)

- Address the various factors that contribute to capital flight and address the problem of illicit financial flows (DOD Para 11);

- Combat corruption (DOD 12);

- Enhanced financial information and transparency, stronger cooperation among national regulators (DOD 51).

This represents a significant progress since 2002, even if most of these points are only formulated as problems to be considered or studied without providing concrete policy proposals and actions. Nonetheless, despite strong civil society support for the inclusion of these points in the Doha outcome document, several countries, among them Canada, New Zealand, USA, and others have been demanding the removal of the proposal to upgrade the UN Committee of Experts (paragraph 10) from the DOD and the watering down of other proposals (TJN Blog September 29, 2008). This upgrade proposal has support from the G77 group of developing countries, and in October 2008 development ministers of the European Union agreed to support the proposals of paragraph 9, 10 and 11 in the Doha outcome document, including strengthening of the UN Tax Committee (though they did not go so far as to support its upgrading to inter-governmental status). Quite separately, the Economic and Monetary Council of the European Parliament has called on the European Commission to ask the International Accounting Standards Board (IASB) to develop an international financial reporting standard for country-by-country reporting on the activities of multinational companies. It has also called on the Commission

"to include measures to prevent capital flight in its policies (...), with the goal of closing down tax havens, some of which are located within the EU or operate in close connection with Member States".

The Council has also called upon the Commission and Member States to -

\footnotetext{
${ }^{6}$ See also: Lesage, D. (2008) Taxation and the 2008 UN Follow-up Conference on Financing for Development: Policy Recommendations. Discussion Paper (forthcoming, to be published in Studia Diplomatica 61, 2008), Ghent University Belgium
} 
"promote the global extension of the principle of the automatic exchange of tax information, to ask that the Code of Conduct on tax evasion currently being drawn up at the United Nations Economic and Social Council (UN ECOSOC) be annexed to the Doha declaration and to support the transformation of the UN Committee of Experts on International Cooperation in Tax Matters into a genuine intergovernmental body equipped with additional resources to conduct the international fight against tax evasion alongside the OECD".

The German Minister for Economic Cooperation and Development, Heidemarie WieczorekZeul, has proposed that stakeholders both from industrialised and developing countries should adopt an International Tax Compact as an effective contribution to combating tax flight. This compact should

- strengthen the tax and customs systems in developing countries;

- promote an exchange of information on financial activities among participants' authorities;

- introduce an exchange of information on best practices among participants; and

- monitor activities of territories where prevailing conditions encourage.

\section{Conclusions}

Ten years after the launch of the OECD's harmful tax competition initiative, and six years after the agreement of the Monterrey Consensus, tax is firmly established on the development agenda. President-elect Barack Obama is a signatory to the Stop Tax Haven Abuse Act, first put to the US Senate in 2006, and widely considered to be a key part of the incoming President's fiscal package. The European Union has accelerated its process for strengthening its Savings Tax Directive to widen its scope to include legal persons such as companies and trusts, and to broaden its geographical coverage. And civil society organisations across the globe are rapidly increasing their capacity to work on tax related issues.

The tax competition agenda that has been so heavily promoted by neo-conservative organisations in America and their associated offshoots and think-tanks in Europe and elsewhere, is challenged by a variety of forces. Empirical research has shown that tax incentives serve little useful purpose in attracting genuine foreign direct investment and in many circumstances distorts capital flows in ways that are harmful. It is also increasingly clear that tax competition shifts the tax charge from capital to workers and consumers, reducing job creation and slowing growth. Furthermore, tax competition, and in particular the abusive tax practices enabled by tax havens, harms public confidence in tax laws and democratic systems of government. International pressure is increasing for tax evasion to be treated as a corrupt practice under the United Nations Convention Against Corruption, and as a predicate offence for anti-money laundering legislation. The stage is thus being set for a major strengthening of regional and international cooperation to counter harmful tax practices.

\section{Appendix 1: The Tax Justice Network agenda}


The Tax Justice Network has taken a lead role in promoting a new tax agenda for pro-poor development. It has led the civil society calls for a new tax agenda to be agreed at the Monterrey review conference at Doha, and has actively campaigned for key measures, including:

- Upgrading the UN Tax Committee to inter-governmental status to help this Committee become the principal forum within which norms for multilateral tax cooperation can be agreed;

- Adopting a UN Code of Conduct on International Cooperation in Combating Tax Evasion, to create a benchmark for testing the actions of secrecy jurisdictions and the financial professionals who promote tax evasion services;

- Pushing for tax evasion to be treated as a corrupt practice under the UN Convention Against Corruption, and as a predicate crime under the AML regimes of all countries providing financial services to non-resident clients;

- Adopting an international accounting standard for country-by-country reporting by multinational companies. TJN has just made a corresponding submission to the International Accounting Standard Board, IASB (TJN Blog, October 3, 2008).

In addition, TJN has proposed that the International Monetary Fund should:

- include in its Reports on Observance of Standards and Codes (ROSCs) whether a jurisdiction that hosts an offshore financial centre complies with standards of international financial transparency, including matters relating to banking secrecy, disclosure of ownership and effective exchange of information;

- monitor and publicize the implementation of the work of institutions working on transparency and exchange of information issues.

At European Union level, TJN has called for:

- Strengthening and broadening of the EU Savings Tax Directive and entering into information exchange agreements based upon the principle of automatic exchange with countries outside the Union. The Directive should include other types of income than interest and other types of recipients than individual;

- Requiring European secrecy jurisdictions and their dependent territories to:

- provide full public disclosure of the beneficial ownership of all legal entities registered under their jurisdiction;

- abolish banking secrecy arrangements;

- demonstrate their capability to engage in effective information exchange; and

- require all professionals covered by $A M L$ regulations to automatically submit suspicious activity reports for each and every client who they suspect of tax evasion. 


\section{Bibliography}

Avi-Yonah, R. (2000) 'Globalization, Tax Competition and the Fiscal Crisis of the Welfare State’, Harvard Law Review 13:1573.

Avi-Yonah, R. (2003) 'Globalization and Tax Competition: implications for developing countries' conference paper presented to the $11^{\text {th }}$ meeting og the United Nations Ad Hoc Group of Experts on International Cooperation in Tax Matters, Geneva, 15-19 December

Center for Freedom and Prosperity (2003) Memorandum: The Level Playing Field: Misguided and Non-Existent, from Daniel J. Mitchell, Heritage Foundation Senior Fellow, dated $10^{\text {th }}$ October 2003

Christian Aid (2008) Death and Taxes: the true toll of tax dodging, Christian Aid, London

Christensen, J. and Kapoor, S. (2004) Tax Avoidance, Tax Competition and Globalisation: making tax justice a focus for global activism, paper given at Tax and Development Conference, Helsinki, Finland, 18-20 November

Christensen, J. and Spencer, D. (2008) Stop this timidity in ending tax haven abuse, Financial Times, Comment, $5^{\text {th }}$ March

Christensen, J. (2008) Welcome to a World Without Rules, Key note speech given at Skettereviorenes Forening, conference on Tax Havens - Corporate Paradises and Community Hell, Elverum, Norway, September

Diesch Peter, Tax competition and its effects on domestic and global justice. University of Montréal, July 2007 (draft paper).

Drezet, V (2005) Vers une accélération de la concurrence fiscale: Des fiscalités en Europe à la fiscalité européenne : quels enjeux? Paris

The Economist (2007) 'Unintended Consequences: the less obvious uses of tax havens', in A Place in the Sun: A special report on offshore finance, $24^{\text {th }}$ February,

Garretsen, H. and Peeters, J. (2006) Capital Mobility, Agglomeration and Corporate Tax Rates: Is the race to the bottom for real? De Nederlansche Bank Working Paper No. 11, September

Global Financial Integrity, Capital flight from the Democratic Republic of Congo, Washington 2008.

Greenpeace International (2008) Conning the Congo, www.greenpeace.org/international/press/reports/conning-the-congo

Gupta, Sanjeev and Tareq Shamsuddin, Mobilizing Revenue, in: IMF Finance and Development, Washington, September 2008, Vol. 45, No. 3.

Lesage, Dries, Taxation and the 2008 UN Follow-up Conference on Financing for Development: Policy Recommendations. Discussion Paper (forthcoming, to be published in Studia Diplomatica 61, 2008), Ghent University Belgium, 2008 
Lynch, R (2004) Rethinking Growth Strategies - how State and Local Taxes and Services Affect Economic Development, Economic Policy Institute, Washington

McKinsey and Company (2004) The McKinsey Quarterly 2004 - 1. Research by McKinsey highlights the ineffectiveness of incentives, including tax breaks, in attracting foreign investment.

Organisation for Economic Cooperation and Development (1998) Harmful Tax Competition: An Emerging Global Issue, OECD, Paris

Qiu, L (2003) Comparing Sectoral FDI Incentives: Comparative Advantages and Market Opportunities, Annals of Economics and Finance, 4: pp383-408

Piatkowski, Marcin and Jarmuzek, Mariusz, Zero Corporate Tax in Moldovia: Tax Competition and Its Implications for Eastern Europe, IMF Working Paper

Radaelli, C. (2003) The Code of Conduct Against Harmful Tax Competition: Open Method of Coordination in Disguise? Public Administration, Volume 81, Number 3, pp515-531

Spencer, David, OECD Proposals on harmful tax practices. A status Report, in: Journal International Taxation, October 2006 (part 1) and November 2006 (part 2), New York.

Spencer, David, Liechtenstein and the Subprime Crisis, in: Journal of International Taxation, September 2008 and October New York 2008.

UNO, General Assembly, The latest developments related to the review process on financing for development and the implementation of the Monterrey Consensus. Report of the Secretary-General, 28 July 2008 /A/63/179.

UNCTAD (2000) Tax Incentives and Foreign Direct Investment: A Global Survey, Geneva

UNO, Draft outcome document of the Follow-up International Conference on Financing for Development to Review the Implementation of the Monterrey Consensus, 28 July 2008/A/Conf.212/CPR.1.

\section{Tax Justice Network:}

TJN Blogs: http: / /taxjustice.blogspot.com/

TJN Website: http://www.taxjustice.net

Tax Justice Focus (Quarterly Newsletter):

http://www.taxjustice.net/cms/front_content.php?idcat=6 (mainly No 4, Vol.2, 2006)

TJN Briefing Paper on Tax Competition

http: / / www.taxjustice. net/cms/front_content.php?idcat=109

Guindja, P. and Christensen, J (2005) 'The Africa Question: Where do all the profits go?' Tax Justice Focus, vol.1, nr 1, Spring edition

Murphy, R., Christensen, J. and Kapoor, S. (2007) Closing the Floodgates, Tax Justice Network, London 
tax justice network

TJN Resource Paper on International Tax Co-operation and Competition http:// www.taxjustice.net/cms/front_content.php?idcat=102

Tax us if you can - the true story of a global failure, London 2005 